\title{
Pemberdayaan PKBM Bina Bangsa Tangerang dalam Mendukung Promosi Pencegahan Penyebaran COVID-19
}

\author{
Wulandari $^{*}$, Yesi Puspita Dewi ${ }^{2}$ \\ ${ }^{1,2}$ Sistem Informasi, Fakultas Teknologi Informasi, Universitas Budi Luhur \\ Jl. Ciledug Raya, Petukangan Utara, Jakarta Selatan 12260 \\ Email Penulis Korespondensi: wulandari@budiluhur.ac.id
}

\begin{abstract}
The Community Learning Activity Center (PKBM) is a non-formal educational institution as an effort to solve problems related to school dropout and unemployment problems (Fasli \& Supriadi, 2001), PKBM Bina Bangsa Larangan Tangerang is a partner in the community service program organized by Budi Luhur University. During this pandemic, the Bina Bangsa PKBM was the hardest to carry out promotions, currently, the promotion carried out by the Bina Bangsa PKBM was carried out through the mouth. So that PKBM Bina Bangsa has difficulty adding the number of new students. To support government activities in preventing Covid-19, the Budi Luhur University lecturer team wants to help PKBM Bina Bangsa Ban in increasing the number of new students by creating a website as a means of media promotion through online media. The goal is that with the existence of a website profile, PKBM Bina Bangsa can be recognized by the wider community. In making the website profile, the Budu Luhur University lecturer team used PHP to develop, after the program was completed, it was tested by blackbox testing. After that, 5 teachers/admins were trained, previously the teacher/admin had never known the features found on a website. After the training was held, the teacher/admin's understanding ability increased so that it is hoped that this website profile will assist PKBM in promoting and helping the government prevent the spread of Covid-19 through online registration without having to face to face.
\end{abstract}

\section{Keywords: PKBM, PHP, PKBM Bina Bangsa, Website}

\begin{abstract}
Abstrak
Pusat Kegiatan Belajar Masyarakat (PKBM) merupakan lembaga pendidikan nonformal sebagai upaya pemecahan masalah yang terkait dengan masalah putus sekolah maupun masalah pengangguran (Fasli \& Supriadi, 2001), PKBM Bina Bangsa Larangan Tangerang merupakan mitra dalam program pengabdian masyarakat yang diselenggarakan oleh Universitas Budi Luhur. Dimasa pandemi ini PKBM Bina Bangsa terkendala dalam melakukan promosi, saat ini promosi yang dilakukan oleh PKBM Bina Bangsa dilakukan melalui mulut kemulut. Sehingga PKBM Bina Bagsa kesulitan dalam menambah jumlah siswa baru. Guna mendukung kegiatan pemerintah dalam pencegahan Covid-19 maka tim dosen Universitas Budi Luhur ingin membantu PKBM Bina Bangsa Larangan dalam meningkat jumlah siswa baru dengan caranya yaitu membuat website sebagai sarana media promosi melalui media online. Tujuanya adalah dengan adanya website profile tersebut PKBM Bina Bangsa dapat dikenal oleh masyarakat luas. Pada pembuatan website profile tim dosen Universitas Budu Luhur menggunakan PHP untuk mendevelop, setelah program selesai dibuat dilakukan pengujian secara blackbox testing. Setelah itu dilakukan pelatihan terhadap 5 guru/admin, yang sebelumnya guru/admin belum pernah mengetahui fitur-fitur yang terdapat pada sebuah website. Setelah diadakan pelatihan tersebut kemampuan pemahaman guru/admin meningkat sehinggan diharapkan dengan adanya website profile ini membantu pihak PKBM dalam melakukan promosi dan membantu pemerintah mencegah penyebaran Covid-19 melalui pendaftaran yang dilakukan secara online tanpa harus tatap muka.
\end{abstract}

\section{Kata kunci: PKBM, Website, PHP, PKBM Bina Bangsa}




\section{PENDAhUluaN}

Pusat Kegiatan Belajar Masyarakat atau biasa disebut dengan PKBM merupakan salah satu lembaga yang bergerak dalam bidang Pendidikan (Dewi \& Wulandari, 2020). PKBM merupakan organisasi masyarakat yang menyelenggarakan pendidikan nonformal sebagai upaya pemecahan masalah yang terkait dengan masalah putus sekolah maupun masalah pengangguran (Fasli \& Supriadi, 2001). Pusat Kegiatan Belajar Masyarakat (PKBM) merupakan salah satu alternatif yang dapat dipilih dan dijadikan ajang pemberdayaan masyarakat (Sihombing, 2001). PKBM Bina Bangsa merupakan salah satu lembaga pendidikan nonformal yang berlokasi di $\mathrm{Jl}$. Komp. Sawah Indah kp. Gaga Larangan Selatan No.27, Larangan Selatan, Kec. Larangan, Kota Tangerang Provinsi Banten. PKBM yang diketuai oleh Drs. Sutoro, PKBM Bina Bangsa berdiri mulai tahun 2002 dan memiliki peserta didik Paket C sebanyak 177 siswa. Dalam melaksanakan kegiatan belajar mengajarnya, PKBM Bina Bangsa dibantu 9 orang Guru Pengajar. Saat ini PKBM Bina Bangsa sudah terakreditasi B.

Dalam menjalani bisnisnya pihak PKBM Bina Bangsa mengalami kendala dalam melakukan kegiatan belajar dan promosi, sebab proses bisnis yang dikerjakan dilakukan dengan cara tatap muka. Penerapan PSBB di lingkungan kota Tangerang membuat pihak sekolah kesulitan untuk melakukan promosi yang dikakukan hanya dari mulut ke mulut.. Hal ini menjadikan PKBM Bina Bangsa sulit untuk mencapai target-targetnya, salah satu target yang ingin dicapai adalah menambah jumlah calon siswa. PKBM Bina Bangsa ingin tetap berkembang dan semakin dikenal oleh masyarakat luas, tetapi tetap mematuhi dan mendukung upaya pemerintah dalam mencegah penyebaran virus Covid-19 (Jurnal.id., 2020) .

Upaya yang dilakukan oleh PKBM Bina Bangsa adalah mempunyai website profile resmi. Hal tersebut yang mendorong tim dosen PPM Fakultas Teknologi Informasi Universitas Budi Luhur melakukan pengabdian kepada masyarakat di PKBM Bina Bangsa Untuk memberikan tawaran/solusi dari masalah yang dialami oleh Pihak PKBM. Sesuai dengan Kewajiban kepada setiap Perguruan Tinggi sebagaimana dijelaskan dalam Tridharma Perguruan Tinggi adalah Pendidikan, Penelitian, dan Pengabdian Masyarakat (Arieef, n.d.). Salah satu bentuk kewajiban tersebut di Universitas Budi Luhur adalah melaksanakan Kegiatan Pengabdian Masyarakat.

Program Kegiatan Pengabdian Masyarakat yang ditawarkan adalah Pembuatan Website Profile Sekolah Sebagai Sarana Promosi untuk Mendukung Usaha Pencegahan Penyebaran Virus Covid-19 Pada Pusat Kegiatan Belajar Masyarakat (PKBM) Bina Bangsa Tangerang yang diharapkan menjadi solusi dari masalah yang dialami pihak PKBM. Dengan adanya website profile tersebut diharapkan promosi yang biasa dilakukan dari mulut ke mulut dapat dilakukan melalui internet sehingga masyarakat luas mengetahui dan tertarik untuk mendaftaran diri sebagai calon siswa PKBM Bina Bangsa melalui website sekaigus tetap mematuhi aturan dari pemerintah agar tidak melakukan kegiatan tatap muka selama pandemi.

\section{METODE PELAKSANAAN}

\section{Waktu dan Tempat Pelaksanaan}

Kegiatan pelatihan pengabdian masyarakat ini dilakukan pada pada tanggal 15 Agustus 2020 diikuti oleh 5 guru dari PKBM Bina Bangsa secara Daring.

\section{Alat dan Bahan: \\ Media yang digunakan pada kegian pengabdian masyarakat ini yaitu: Komputer yang tekoneksi dengan internet, gmeet, panduan materi pelatihan. \\ Metode yang digunakan dalam kegiatan pengabdian masyarakat ditunjukan pada gambar 1.}

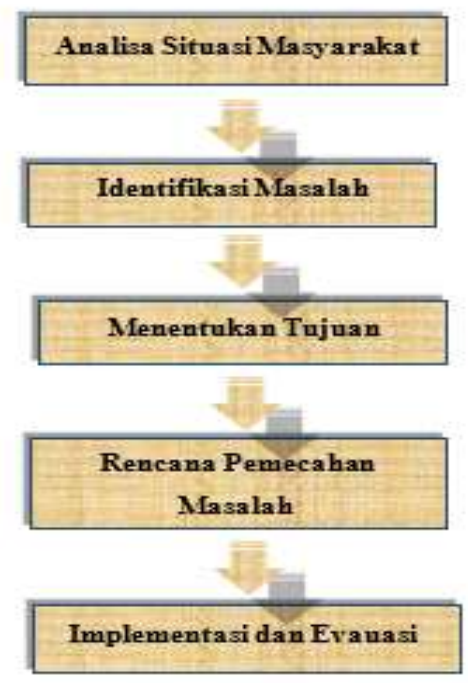

Gambar 1. Bagan Metode Pelaksanaan 
Tabel 1 Tahapan Kegiatan Pengabdian Masyarakat

\begin{tabular}{|c|c|c|}
\hline No & Kegiatan & $\begin{array}{l}\text { Waktu(Bulan, } \\
\text { minggu Ke-) }\end{array}$ \\
\hline 1 & $\begin{array}{l}\text { Analisa Situasi } \\
\text { Masyarakat: analisa } \\
\text { kebutuhan dan } \\
\text { wawancara }\end{array}$ & $\begin{array}{l}\text { April, minggu } \\
\text { ke-3 s/d Mei, } \\
\text { minggu ke-2 }\end{array}$ \\
\hline 2 & $\begin{array}{l}\text { Identifikasi Masalah: } \\
\text { belum memiliki media } \\
\text { promosi }\end{array}$ & $\begin{array}{l}\text { Mei minggu ke } \\
3 \text { s/d minggu ke } \\
4\end{array}$ \\
\hline 3 & $\begin{array}{l}\text { Menetukan } \\
\text { Tujuan:yaitu } \\
\text { pembuatan website } \\
\text { profile }\end{array}$ & $\begin{array}{l}\text { Juni Minggu ke- } \\
1\end{array}$ \\
\hline 4 & $\begin{array}{l}\text { Rencana Pemecahan } \\
\text { Masalah: mendevelop } \\
\text { website dan pelatihan } \\
\text { penggunaan site }\end{array}$ & $\begin{array}{l}\text { Juni minggu ke } \\
2 \text { s/d juli } \\
\text { minggu ke } 4\end{array}$ \\
\hline 5 & $\begin{array}{l}\text { Impelementasi dan } \\
\text { Evaluasi: } \\
\text { testing/pengujian } \\
\text { website. }\end{array}$ & $\begin{array}{l}\text { Agustus minggu } \\
\text { ke } 1 \text { s/d agustus } \\
\text { minggu ke } 4\end{array}$ \\
\hline
\end{tabular}

Keterangan:

a. Analisa Situasi Masyarakat

Dalam tahap analisa situasi, pengusul melakukan pertemuan dengan pihak PKBM Bina Bangsa untuk menganalisa kebutuhan dan melakukan wawancara. Saat ini PKBM Bina Bangsa sudah memiliki izin dengan No: 421.10/Kep. 578/BPPT/Kesra/PKBM 009/2010 dan sudah terakreditasi B. Dalam melakukan kegiatan promosi PKBM Bina Bangsa masih menggunakan sistem dari mulut ke mulut sehingga untuk menjaring siswa baru masih sangat sulit. Upaya yang dilakukan PKBM dalam menjaring siswa baru yaitu dengan mengembangkan melalui media sosial yaitu Instagram pkbm_binabangsa. Gambar Instagram PKBM Bina Bangsa ditunjukan kan pada gambar 2.
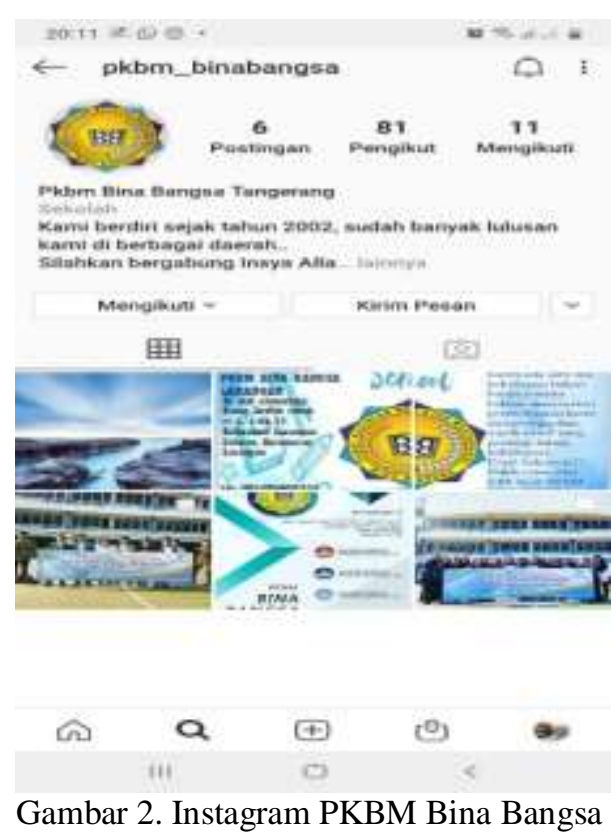

Namun dari media sosial tersebut masih belum maksimal dalam menjaring siswa baru untuk bergabung dengan pihak PKBM Bina Bangsa.

b. Identifikasi Masalah

Dalam Tahapan Identifikasi permasalah yang dialami oleh PKBM Bina Bangsa kesulitan mendapatkan siswa baru dikarenakan kegiatan promosi dilakukan dari mulut ke mulut dan belum memiliki media yang menampilkan profile, portofolio maupun gambaran kegiatan PKBM Bina Bangsa.

c. Menentukan Tujuan

Dalam tahapan menentukan Tujuan, yaitu mejadikan website profile sebagai media promosi sekaligus memberikan informasi ke masyarakat umum terkait kegiatan yang terdapat pada PKBM Bina Bangsa seperti ptofile, kegiatan, informasi pendaftaran, dll.

d. Rencana Pemecahan Masalah

Dalam tahapan pemacahan masalah di bagi menjadi dua tahan yaitu:

- Membangun website profil menggunakan PHP.

- Melakukan pelatihan ke pihak PKBM Binabangsa agar mengerti cara penggunaan website. 
e. Implementasi dan Evaluasi

Dalam Tahapan Evaluasi dibagi menjadi 2 tahapan yaitu

- Melakukan pengujian terhadap website menggunakan Blackbox Testing sebelum dibuat live.

- Melakukan Pengujian Validasi, yaitu kesesuaian antara permintaan pihak PKBM dengan program yang telah dibuat sesuai dengan kebutuhan fungsionalnya

\section{HASIL DAN PEMBAHASAN}

Dalam mendukung usaha pemerintah dalam pencegahan Covid-19 seluruh kegiatan pengabdian masyarakat dilakukan secara daring, termasuk dalam kegiatan promosi PKBM Bina Bangsa melalui pembuatan website profile agar PKBM Bina Bangsa dapat dikenal masyarakat luas. Alamat link website PKBM Bina Bangsa yaitu http://pkbmbinabangsa.id. Adapun Kebutuhan sistem yang dibutuhkan untuk membuat website profile PKBM Bina Bagsa, kebutuhan website tersebut dibagi menjadi 2:

a. Font End terdapat menu-menu yaitu Home, Profile ,Berita ,Galery,Pendaftaran, Contact Us.

b. Back End terdapat fasilitas untuk login, membuat Postingan/Content, Edit Postigan, Tambah User, Tambah Kategori/Tag.

Tampilan website profile PKBM Bina bangsa ditunjukan pada Gambar 3.

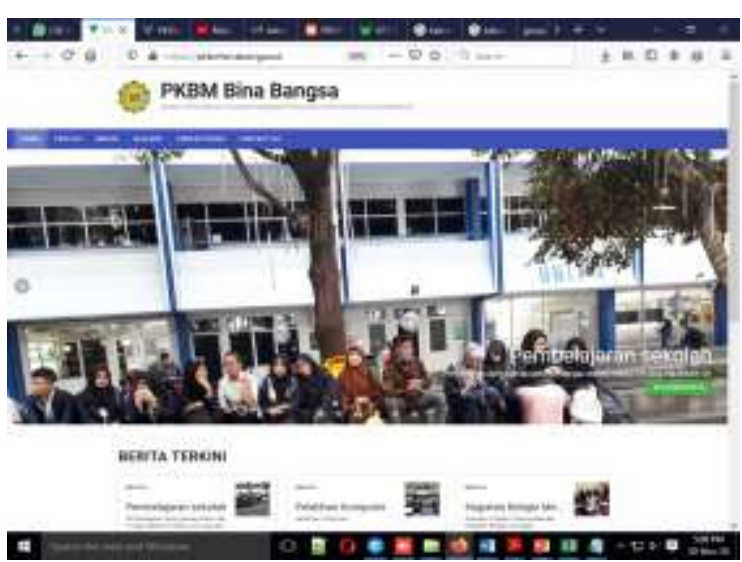

Gambar 3. Tampilan Website PKBM Bina Bangsa
Tampilan form pendaftaran calon siswa baru yang terdapat pada website profile PKBM bina bangsa ditunjukan pada Gambar 4.

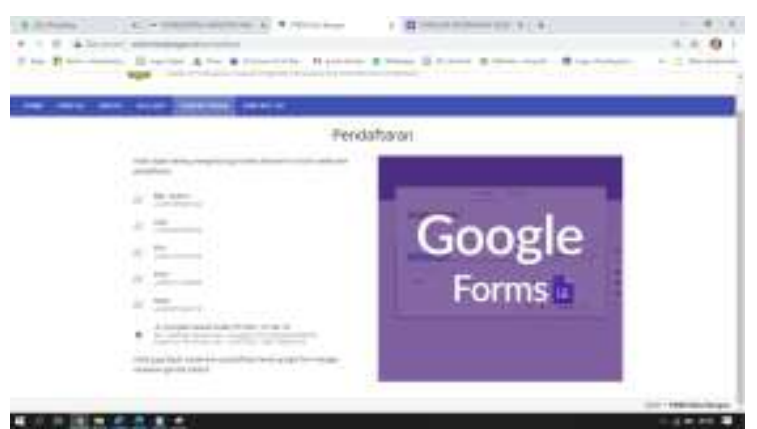

Gambar 4. Form Pendaftaran Calon Siswa Baru

Sebelum melakukan pelatihan terlebih dahulu website di ujicoba terlebih dahulu menggunakan pengujian blackbox testing. Pengujian tersebut dilakukan dengan cara memberikan inputan ke program, Dari inputan dapat dilihat apakah program yang dibuat dapat menghasilkan output sesuai dengan kebutuhan PKBM. Berikut ini beberapa pengujian yang dilakukan terhadap website http://pkbmbinabangsa.id.

a. Pengujian Menu Login

Pengujian menulogin ditunjukan pada Gambar 5.

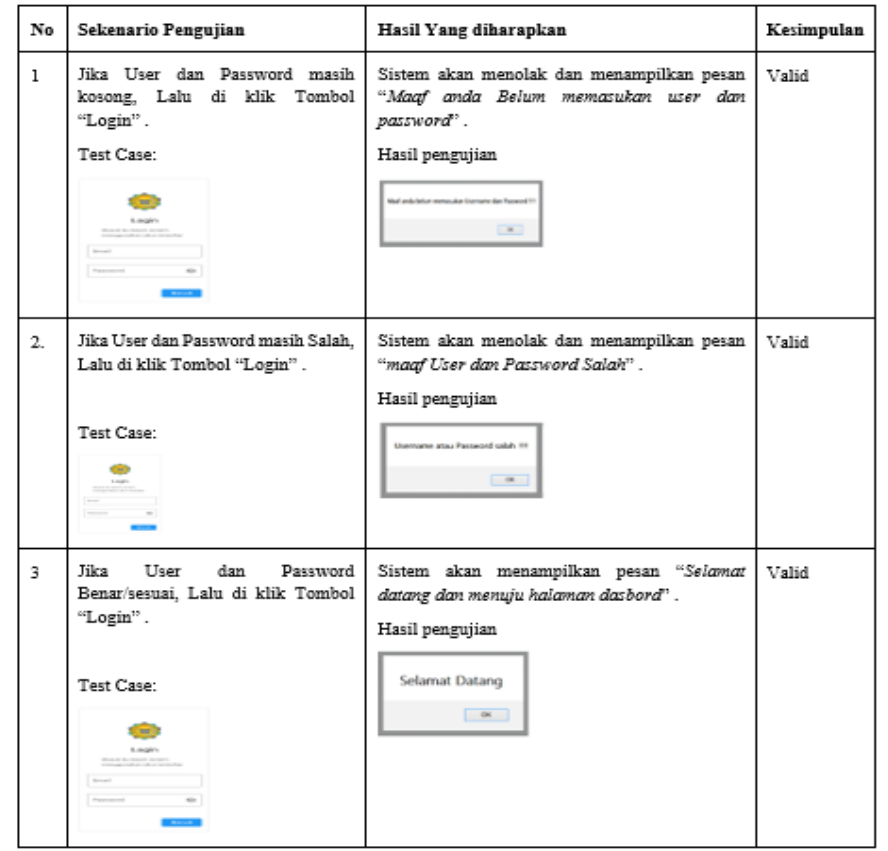

Gambar 5. Pengujian Menu Login 
b. Pengujian Menu Content/Membuat Postingan

Pengujian menu content/membuat postingan ditunjukan pada Gambar 6 .

\begin{tabular}{|c|c|c|c|}
\hline No & Sekenario Pengujian & $\begin{array}{l}\text { Hasil Yang } \\
\text { diharapkan }\end{array}$ & Kesimpulan \\
\hline 1 & $\begin{array}{l}\text { Jika user belum lengkap mengigi } \\
\text { postingan/content, lalu di klik tombol } \\
\text { "simpan" } \\
\text { Test Case: }\end{array}$ & $\begin{array}{l}\text { Sistem akan } \\
\text { menolak dan } \\
\text { tombol } \\
\text { "SIMPAN" akan } \\
\text { di HIDE/dibuat } \\
\text { tidak menyala } \\
\text { Hasil pengujian } \\
\end{array}$ & Valid \\
\hline 2. & $\begin{array}{l}\text { Jika user Sudah lengkap mengisi } \\
\text { postingan /content, lalu di klik tombol } \\
\text { "simpan" } \\
\text { Test Case: }\end{array}$ & $\begin{array}{l}\text { Tombol } \\
\text { "SIMPAN" akan } \\
\text { menyala dan } \\
\text { simpan, lalu } \\
\text { postingan akan } \\
\text { tampil di home. } \\
\\
\text { Hasil pengujian }\end{array}$ & Valid \\
\hline
\end{tabular}

Gambar 6. Pengujian Menu Content

Hasil pengujian terhadap website tidak terdapat eror dan parameter sesuai dengan kebutuhan. Berdasarkan kesimpulan diatas semua validasi menunjukan "Valid", hal ini menunjukan bahwa website siap untuk digunakan.

Kegitan berikutnya dilanjutkan dengan pembuatan materi pelatihan penggunaan website profile PKBM Bina Bangsa. Contoh materi pelatihan ditunjukan pada Gambar 7.

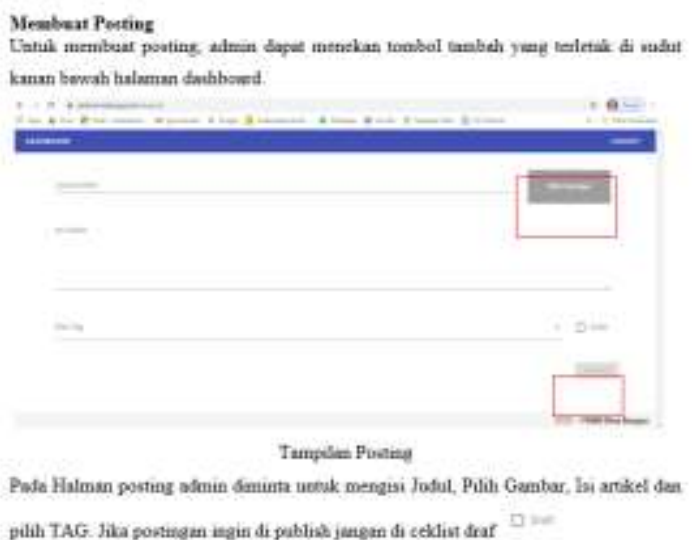

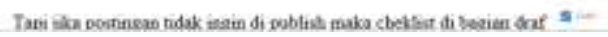

Gambar 7. Contoh Materi Pelatihan Membuat Postingan/Content.
Setelah dilakukan persiapan tahapan berikutnya adalah pelatihan. Kegiatan pelatihan dilaksanakan pada tanggal 15 Agustus 2020 diikuti oleh 5 guru dari PKBM Bina Bangsa secara Daring.

Kegiatan pengabdian tersebut ditunjukkan pada Gambar 8, 9, 10 berikut ini:

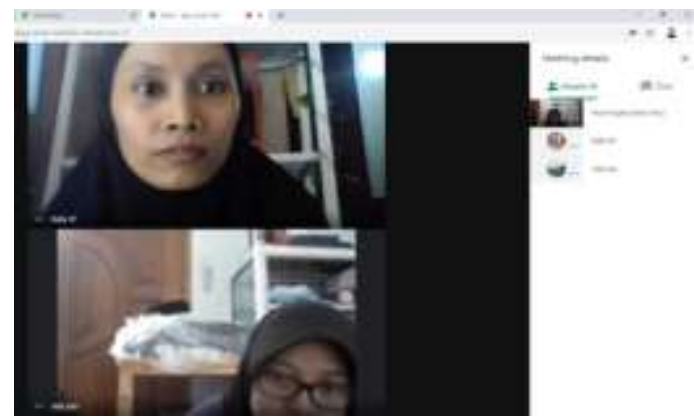

Gambar 8. Pembukaan oleh Instruktur Kegiatan

Gambar 9 Guru/Admin PKBM sedang mempraktikkan teori yang disampaikan.

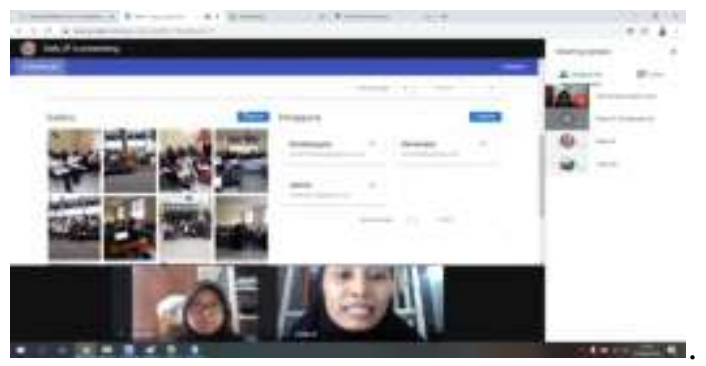

Gambar 9. Admin/Guru PKBM sedang mempratikan teori yang disampaikan.

Pada Gambar 10 setelah selesai pelatihan diadakan foto bersama admin/Guru PKBM Bina bangsa.

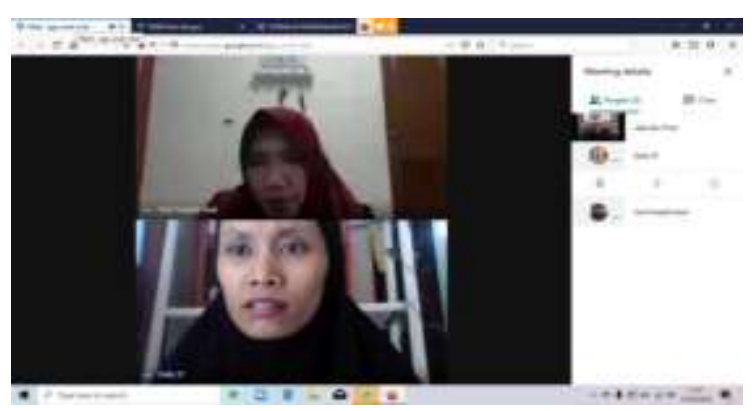

Gambar 10. Foto Instruktur Pelatihan.

Dalam pelatihan ini terlihat para peserta sangat antusias sekali mengikuti pelatihan. Hal ini ditunjukan dengan hasil postingan yang telah di publish di website 
http://pkbmbinabangsa.id. Tampilan postingan ditunjukan pada Gambar 11.

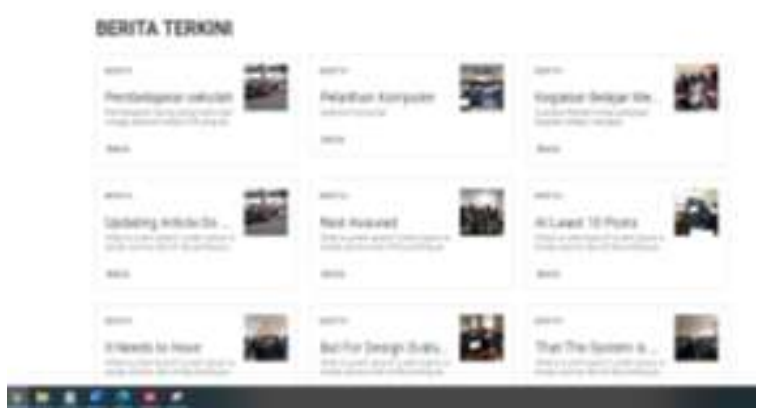

Gambar 11. Hasil Postingan

Sebelum diadakan pelatihan guru/admin belum pernah mengetahui cara menggunakan website. Setelah diadakan pelatihan terhadap ke 5 guru yang nantinya merangkap sebagai admin secara bergantian saat ini sudah mengerti cara login ke website, membuat postingan, edit postingan, hapus postingan dan menambah kategori. Sehingga dapat disimpulkan kemampuan guru/admin meningkat 100\%. Hasil pemahaman terhadap materi yang disampaikan ditunjukan pada Tabel 2.

Tabel 2. Hasil Kepuasan peserta pelatihan

\begin{tabular}{|c|c|c|c|c|c|}
\hline No & Instrument & SS & $\mathrm{S}$ & TS & STS \\
\hline 1. & $\begin{array}{l}\text { Materi Pelatihan } \\
\text { penggunaan Website } \\
\text { yang diberikan } \\
\text { sesuai dengan } \\
\text { kebutuhan }\end{array}$ & 5 & - & - & \\
\hline 2. & $\begin{array}{l}\text { Materi yang } \\
\text { diberikan lengkap } \\
\text { dan mudah dipahami }\end{array}$ & 5 & - & - & - \\
\hline 3. & $\begin{array}{l}\text { Instruktur bekerja } \\
\text { secara profesional } \\
\text { dalam membantu } \\
\text { pemahaman dan } \\
\text { kejelasan mengenai } \\
\text { penggunaan website. }\end{array}$ & 5 & - & - & - \\
\hline 4. & $\begin{array}{l}\text { Saya menguasai } \\
\text { materi pelatihan } \\
\text { yang diberikan } \\
\text { dengan cepat. }\end{array}$ & 4 & 1 & - & - \\
\hline 5. & $\begin{array}{l}\text { Saya berpartisipasi } \\
\text { aktif dalam } \\
\text { pelaksanaan } \\
\text { program pelatihan } \\
\text { penggunaan website }\end{array}$ & 4 & 1 & - & - \\
\hline 6. & $\begin{array}{l}\text { Setelah } \\
\text { mendapatkan materi } \\
\text { Pelatihan }\end{array}$ & 4 & 1 & - & - \\
\hline
\end{tabular}

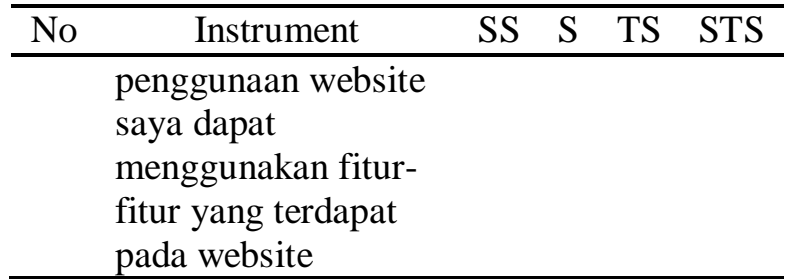

Keterangan:

SS : Sangat Setuju

$S$ : Setuju

TS : Tidak Setuju

STS : Sangat Tidak Setuju

Berdasarkan Tabel 2 diatas dapat dilihat bahwa respon guru/admin dalam mengikuti pelatihan adalah sangat setuju dan setuju. Hal tersebut dapat diartikan bahwa guru/admin puas dalam mengikuti pelatihan yang telah diberikan, sehingga menambah pemahaman akan penggunaan fitur-fitur yang terdapat pada website.

\section{SIMPULAN DAN SARAN}

Berdasarkan hasil pelatihan penggunaan website profile yang dilakukan secara daring maka dapat disimpulkan bahwa adanya peningkatan keterampilan dalam menggunkaan fitur-fitur yang terdapat pada website seperti membuat postingan, edit postingan, hapus postingan dan membuat kategori.

Kegiatan pengabdian masysrakat ini merupakan upaya dalam mengurangi pencegahan penyebaran Covid-19 dan mendukung promosi PKBM Bina Bangsa agar dikenal masyarakat luas.

Kedepanya penggunaan website profile untuk kedepannya dapat dikembangkan lebih lanjut agar menjadi sebuah sistem untuk berkomunikasi antara sekolah dan wali murid.

\section{UCAPAN TERIMA KASIH}

Ucapan terima kasih kepada Fakultas Teknologi Universitas Budu Luhur dan PKBM Bina Bangsa Larangan yang telah mendukung dan berpartisipasi dalam kegiatan pengabdian masyarakat ini. 


\section{DAFTAR PUSTAKA}

Arieef, M. (N.D.). Tri Dharma Perguruan Tinggi. Retrieved From Https://Www.Academia.Edu/4379037/TRI_ DHARMA_PERGURUAN_TINGGI

Dewi, Y. P., \& Wulandari. (2020). Peningkatan Kompetensi Pengolahan Data Sederhana dengan Microsoft Excel 2013 Pada PKBM BINA BANGSA. Jurnal Pemberdayaan Masyarakat Universitas Al Azhar Indonesia, Vol. 02, No. 1, 6- 10.

Fasli, J., \& Supriadi, D. (2001). Reformasi
Pendidikan Dalam Konteks Otonomi Daerah. (F. J. Dan D. Supriadi, Ed.) (Ed.1, Cet.). Yogyakarta: Adi Cita Karya Nusa.

Jurnal.Id. (2020). Tips Agar Bisnis UKM Mampu Bertahan Di Masa Pandemi Corona. Retrieved From Https://Www.Jurnal.Id/Id/Blog/TipsAgar-Bisnis-Ukm-Mampu-Bertahan-DiMasa-Pandemi-Corona/

Sihombing, U. (2001). Pendidikan Luar Sekolah: Masalah, Tantangan, Dan Peluang (Cet. 1). Jakarta: Wirakarsa. 